\title{
BETWEEN REVOLT AND LOYALTY: STUDENTS OF THE AUSTRIAN EMPIRE IN THE 1848 REVOLUTION ${ }^{1}$
}

\author{
Julija E. But \\ Ural Federal University named after the first President of Russia B.N. Yeltsin, Yekaterinburg, Russian Federation
}

\begin{abstract}
Introduction. As a social group with its specific features and motivation, students have been long characterized by their active involvement in social and political unrest. However, the behavioral analysis of students in different historical situations has become an independent research topic as late as in the 1960s. Numerous nuances of student activity remain for that reason unexplored. That is true of the process of student politicization and nationalization in the multi-ethnic Austrian empire during the tumultuous year of 1848. In literature, this issue is either pushed aside or based on an image of a radical "Austrian" student helping proletarians to fight against the regime on barricades. The latter is not relevant in view of the diversity of student sentiments and ideas that were present in the vast Habsburg hereditary lands. Methods and materials. This article analyzes students' sympathies and actual participation in the rebellious events of 1848 considering the cases of two universities - that of the capital city of Vienna and the university of provincial Innsbruck. The study is based on students' memoires, pamphlets, letters and newspapers of that time, as well as official documents and appeals by the government. Analysis. The analysis shows that Viennese students had an effective voice in revolutionary events, but their demands were of relatively moderate liberal character, while they largely remained loyal to the emperor. The revolutionary activity of provincial students was much more modest and peaceful than in Vienna. In case of Innsbruck, in particular, an image of a patriotic student fighting with arms for his emperor and fatherland replaced the image of a student fighting for political freedoms. Results. The participation of students in the revolutionary events of 1848 resulted in politicization of the "Austrian" student body and its consolidation as an independent social group.
\end{abstract}

Key words: $19^{\text {th }}$ century, Habsburgs, Austrian Empire, revolutions of 1848 , student revolt, history of universities, national movement, educational elite.

Citation. But Ju.E. Between Revolt and Loyalty: Students of the Austrian Empire in the 1848 Revolution. Vestnik Volgogradskogo gosudarstvennogo universiteta. Seriya 4. Istoriya. Regionovedenie. Mezhdunarodnye otnosheniya [Science Journal of Volgograd State University. History. Area Studies. International Relations], 2020, vol. 25, no. 2, pp. 27-43. (in Russian). DOI: https://doi.org/10.15688/jvolsu4.2020.2.2

\section{МЕЖДУ БУНТОМ И ПРЕДАННОСТЬЮ: СТУДЕНЧЕСТВО АВСТРИЙСКОЙ ИМПЕРИИ В РЕВОЛЮЦИОННЫХ СОБЫТИЯХ 1848 ГОДА ${ }^{1}$}

\author{
Юлия Евгеньевна Бут \\ Уральский федеральный университет им. первого Президента России Б.Н. Ельцина, \\ г. Екатеринбург, Российская Федерация
}

\footnotetext{
Аннотация. Студенчество как социальная группа, обладающая специфическими чертами и мотивацией, всегда отличалась активной вовлеченностью в социально-политические волнения и беспорядки. Между тем поведенческий анализ студенчества в разных исторических ситуациях начал привлекать интерес исследователей только с конца 1960-х годов. В связи с этим многие моменты и нюансы в эволюции феномена студенческой активности остаются неизученными. Это касается, в частности, процессов политизации и национализации студенчества в полиэтничной Австрийской империи в эпохальный для европейских народов 1848 год. В историографии до сих пор сохраняется устойчивый образ «австрийского» студента-радикала, борца с режимом, помощника пролета-
} 
риата. Сложившееся представление не учитывает всю пестроту студенческих настроений и мировоззрения в обширных регионах австрийских наследственных земель. В данной статье анализируются настроения, требования и фактическое участие в общественно-политических событиях 1848 г. столичного студенчества Вены и провинциального студенчества на примере Инсбрука. Материалом для исследования послужили воспоминания современников, студенческие листовки, памфлеты, письма, газеты, а также официальные документы и обращения властей. Анализ фактического материала показал, что даже студенчество имперской столицы, громко заявившее о себе в революционных событиях, имело относительно умеренные требования либерального характера и при всех своих повстанческих действиях продолжало сохранять лояльность императору. Революционная деятельность провинциальных студентов имела еще более скромное и мирное выражение. В частности, в случае Тироля образ студента-патриота, сражающегося с оружием в руках за отечество и императора, вытеснил образ студента-борца за политические свободы. В целом участие студентов в революционных событиях 1848 г. привело к политизации «австрийского» студенчества и его сплочению как самостоятельной социальной группы.

Ключевые слова: ХІХ век, Габсбурги, Австрийская империя, революция 1848 года, студенческие протесты, история университетов, национальные движения, образованная элита.

Цитирование. Бут Ю. Е. Между бунтом и преданностью: студенчество Австрийской империи в революционных событиях 1848 года // Вестник Волгоградского государственного университета. Серия 4, История. Регионоведение. Международные отношения. - 2020. - Т. 25, № 2. - С. 27-43. - DOI: https://doi.org/10.15688/ jvolsu4.2020.2.2

Введение. В связи с тем, что студенчество характеризуется четким осознанием своей принадлежности к особой социальной группе, студенческие волнения и протесты на протяжении всей истории являлись неотъемлемой частью университетской жизни. Начиная со Средних веков привилегированное положение студенчества, считавшегося частью социальной элиты, во многом сформировало его традиционно критическое отношение к окружающей среде, внутренней жизни университета и общей социально-политической обстановке в государстве. На протяжении столетий у студентов росла уверенность в собственных возможностях оказывать влияние на общественные устои и в том, что любые их действия будут снисходительно восприняты обществом и не будут строго наказаны [12, p. 2]. Изучение студенчества как критически мыслящей городской прослойки и анализ студенческих протестов на европейском континенте долгое время оставались за рамками исследований ученых. Интерес к роли студенчества в общественно-политических волнениях появился в работах историков, социологов и политологов только начиная с 1960-х гг., после того как этот феномен приобрел мировой размах. Исследователи, стремившиеся выявить «корни и почву» участия студентов в протестах, а также специфические черты студенчества, обусловившие его выход на политическую арену, обнаружили, что студенческие движения в отдаленном и недавнем прошлом играли выдающуюся и зачастую ведущую роль, особенно в борьбе за национальное освобождение и объединение и - реже - в восстаниях, ставивших перед собой иные социально-политические цели [10].

В этом контексте интересна роль студенчества в политической жизни Австрийской империи - одного из самых крупных и этнически пестрых государств Нового времени, а также характер влияния, которое учащиеся имперских университетов оказывали на формирование национальной и образовательной политики габсбургского правительства. В XIX в. у полиэтничного «австрийского» студенчества в разные периоды в моде была серьезная учеба или коллегиальная жизнь, реже - военный энтузиазм или романтическое искусство, а также были периоды острой озабоченности социальными проблемами. В одних случаях реформаторский пыл студентов был обращен только на их собственные учебные учреждения, в других случаях был направлен вовне - с желанием изменить целый мир. Считается, что политическая ангажированность студентов, их жажда свободы и солидарность с неимущими слоями общества достигли своего пика в революционных событиях 1848 г., после которых настроения студенчества не накалялись до такого уровня вплоть до 1918 г. [26, р. 367].

Однако эта проблема не получила должного освещения ни в отечественной, ни в зарубежной литературе. В общих работах, по- 
священных революции 1848 г. в Европе, и в Австрийской империи в частности, нередко встречается образ «австрийского» студента как радикала, террориста и экстремиста, борца против законной власти, на баррикадах сражающегося за демократические и республиканские идеи «бок о бок» с рабочими массами. В отечественной литературе позициям студенчества отведено крайне мало внимания: как правило, предпочтение отдается рассмотрению политических программ того периода либо акценту на революционной деятельности рабочего класса, в которой студенчество играло вспомогательную роль (см., например: [1; 3-8]). Так, Е.В. Тарле пишет, что студенты играли роль «высокополезного для революционного дела звена, которое связывало буржуазию с рабочим классом в одном общем деле»; они последними уходили «с арены борьбы» и погибали «при крушении революции рядом с оставленными рабочими» [7, с. 587]. При этом во всех исследованиях «австрийское» революционное студенчество представлено исключительно столичным студенчеством Венского университета. Предполагается, что студенты других университетов Австрийской империи следовали примеру столицы и, будучи гораздо малочисленнее, представляли собой слабое подобие венской организации. Однако такой подход искажает исторические реалии, поскольку в революционных событиях 1848 г. имело место существенное региональное разнообразие в активности студенчества, характере его убеждений и степени лояльности властям.

Методы и материалы. На сегодняшний день в литературе предложено множество объяснений феномена студенческих движений, исходя из психологических, социологических, экономических, культурных и институциональных концепций [24, p. 128]. В работах современных европейских исследователей доминирует подход, в основе которого лежит убеждение, что студенческие протесты на всем пространстве и во все времена имели высокую степень преемственности. При этом они не всегда носили исключительно прогрессивный характер. В них противоречивым образом сочетались передовые идеи и консервативные амбиции, выражавшиеся в отстаивании собственных привилегий или ностальгии «по старым добрым временам». Также особенностью подхода современных историков является пристальное внимание к студенческим ритуалам, символике, флагам, фуражкам, значкам и т. п., использовавшимся в ходе волнений и протестов (см., например: [31]).

В основе данного исследования лежит так называемая политическая теория студенческой активности Ф.А. Пиннера, согласно которой студенчество представляет собой одну из «маргинальных элит» общества, играющую самостоятельную политическую роль во времена кризисов, но в то же время выступающую ненадежным союзником в политических альянсах. Не обладая эффективными средствами принуждения, например оружием или правом религиозных санкций, студенты всегда были более слабой стороной в любом союзе, поэтому в случае победы они получали наименьшие выгоды, а в случае поражения становились легкой мишенью возмездия и объектом репрессий. В результате сложившейся ситуации студенты с достаточной легкостью меняли свои идеологические убеждения и могли легко переходить в оппозицию своим бывшим союзникам [24, p. 127].

Объектом исследования является деятельность «австрийского» студенчества в революционных событиях 1848 года. Под «австрийским» студенчеством здесь понимаются разные по национальности учащиеся университетов, располагавшихся в так называемых австрийских наследственных землях, за исключением Венгерского королевства. Именно в австрийских наследственных землях габсбургское правительство стремилось реализовать идею «австрийской» общеимперской идентичности в противовес формирующимся национальным идентичностям, в том числе с помощью образовательной политики. Усилия имперского правительства не распространялись на территорию Венгерского королевства, в котором мадьярская национальная элита вскоре добилась окончательного успеха при создании дуалистического государства в 1867 году.

Цель настоящей работы - пересмотр сложившегося в историографии образа «австрийского» студента с учетом примеров не только столичного, но и провинциального студенче- 
ства, а также факторов, влиявших на перемены в настроениях, убеждениях и лояльности студентов. Для этого были оценены степень вовлеченности и характер участия в революционных событиях марта - октября 1848 г. не только столичного студенчества Венского университета, но и провинциального студенчества на примере Инсбрукского университета. К сожалению, в рамках данной статьи нет возможности подробно рассмотреть деятельность студенчества остальных «австрийских» университетов. Инсбрукский университет выбран автором как пример наиболее отличных от столицы тенденций.

Исследование основано на воспоминаниях очевидцев событий 1848 г., объемные выдержки из которых собраны в труде австрийского историка Максимилиана Баха, вышедшем в 1898 г. [2]. Также в работе были использованы материалы лаборатории Австрийской национальной библиотеки, Цифрового архива революции 1848 г. и собрания «Исторических австрийских газет и журналов онлайн» (ÖNB-ANNO). Эти материалы включают оцифрованные рукописные и печатные листовки, памфлеты, брошюры, правительственные указы и постановления, официальные обращения властей, настенные объявления и газеты 1848-1849 годов.

Анализ. Революционное студенчество в имперской столице: Венский универсиmem. К середине XIX в. австрийские наследственные земли были лучше других обеспечены университетами. Самый старинный из университетов, Пражский, был основан в 1348 г., в 1364 г. открылся Краковский университет, в 1365 г. - Венский, в 1573 г. - Оломоуцский, в 1586 г. - Грацский, в 1661 г. - Львовский, в 1668 г. - Инсбрукский, в 1672 г. - Линцский. Университет в Зальцбурге, открытый в 1622 г., утратил свой статус, превратившись в 1810 г. в богословско-философский лицей. В первой половине XIX в. австрийское правительство продолжало следовать сложившейся традиции и воспитывать в подданных прежде всего патриотизм и преданность правящей династии [19]. Более того, ужесточился государственный контроль над процессом обучения, а все учебники и программы курсов подлежали обязательному одобрению со стороны правительственных чиновников.
В годы правления императора Франца II (I) Венский университет стал приходить в упадок и вскоре утратил свою прежнюю значимость в научной области. Его главной задачей стало обучение «полезных» подданных, которые станут выполнять свой долг на службе церкви и государству. Правительство с подозрением относилось к новым интеллектуальным течениям, которые расцветали в соседних германских землях, и опасалось, что они могут быть импортированы в Австрийскую империю через университеты. В результате была установлена система надзора и цензуры, во многом соответствовавшая принципами Карлсбадских декретов 1819 года. От профессоров ожидалось, что они будут в точности излагать материал из одобренных правительством учебников, особенно в отношении вопросов, связанных с религией и философией. Если возникало подозрение в том, что на лекции профессор высказывал либеральные или националистические взгляды, он мог лишиться занимаемой им должности [21, р. 122].

Однако предпринятые меры не смогли воспрепятствовать проникновению идей либерализма и конституционализма в земли Габсбургской монархии. На взгляды студентов и ряда преподавателей Венского университета все сильнее оказывали влияние идеи свободы и национальной идентичности. Неудовлетворенность политической системой в целом и условиями обучения в частности росла на протяжении 1840-х гг., пока экономический кризис, разразившийся во всей Европе, не подорвал основы старого порядка. На окраинах Вены воцарились нищета и голод, а перед мелким средним классом, к которому в тот период принадлежало большинство венских студентов, встала угроза опуститься до положения пролетариата. Ситуация была еще более напряженной из-за того, что университет ежегодно выпускал больше специалистов, чем было предложений для их трудоустройства. В предмартовский период правительство намеревалось провести некоторые реформы, по крайней мере в сфере высшего образования, но никаких конкретных мер так и не было принято. Студенческий корпус и буржуазно-либеральная оппозиция, формировавшаяся в тот период, окончательно 
разуверились в том, что правящие власти в состоянии решить назревшие экономические и социальные проблемы, в связи с чем требовали предоставить им право участия в принятии политических решений и разработке реформ [20, p. 77]. Хотя Вена, как и прежде, оставалась «веселым» городом многочисленных праздников и развлечений, в столице габсбургской монархии, по словам Дж. Рата, «уже закипал ведьмин котел» [25, p. 6].

Вена стала единственным городом, где революция началась с собственно студенческого выступления. Во всех остальных местах студенты примкнули к уже восставшим группам населения. В условиях напряженной предреволюционной ситуации около 2000 студентов Венского университета, прежде всего учащиеся факультетов медицины и права, и Политехнического института собрались в воскресенье, 12 марта, на площади перед университетской церковью. Там они выслушали проповедь университетского священника Антона Фюстера - яркого оратора и активного участника революционных событий в будущем, которая только подогрела их оппозиционные настроения [20, p. 77]. Студенты ворвались в главное здание университета, Новую Аулу (Neue Aula), где утвердили проект петиции на имя императора Фердинанда I, в которой изложили свои требования: свобода печати, свобода слова, равенство вероисповеданий, публичность и гласность суда, всеобщее представительство и академические свободы [18, S. 1-2]. Составление петиции было деликатным делом: необходимо выбрать нужный тон и верные слова, одни выражения казались студентам слишком дерзкими, другие - слишком заискивающими, но, наконец, они остановились на показавшемся им как раз подходящим «мужском» выражении и сообщили императору, что «свобода является самым мощным связующим звеном между монархом и его народом» [26, p. 375-376]. Здесь стоит подчеркнуть, что идеи венских студентов не носили радикального характера. Они включили в свою петицию лишь стандартный набор либеральных требований того времени и подписались как «преданные Вашему Величеству студенты Вены».

Интересно, что персона императора никогда не являлась объектом ненависти сту- дентов, как, впрочем, и других жителей столицы. Их чувство преданности монарху было по-прежнему сильным, для них император всегда оставался их любимым «Ферди Добрым». Такие человеческие качества Фердинанда I, как природная доброта и простота, отодвинули его душевную болезнь и рецидивирующие приступы эпилепсии на второй план в восприятии народных масс, среди которых утвердился миф, что их доброму и терпимому императору не дают стать гуманным и либеральным правителем хитрые советники, которые «окутали его завесой темноты и мешают увидеть нужды народа» $[25$, p. 6]. В 1848 г. для разочарованных австрийцев, все еще преданных своему монарху, общепризнанными виновниками всех бед являлись «злобные» бюрократы, «вездесущая» полиция и в особенности два непопулярных политических деятеля, ставших символами горя и репрессий, - начальник полиции граф Йозеф фон Седльницкий (1778-1855) и государственный канцлер князь Клеменс фон Меттерних (1773-1859).

Осознав всю взрывоопасность сложившегося положения, полиция призвала профессоров усмирить «преступную молодежь». Для обсуждения нарастающего конфликта профессора собрались в соседнем с Новой Аулой университетском здании Университетсхаус (Universitätshaus). Они отправили к студентам двух делегатов, пользовавшихся среди них популярностью, - профессоров Антона фон Хая (1807-1894) и Штефана Ладислава Эндлихера (1804-1849), которые договорились представить студенческую петицию при двоpe. На следующий день они сообщили студентам, что ни правительство, ни двор не были готовы удовлетворить ни одно из изложенных в петиции требований. После этого, несмотря на призывы профессора Хая поддерживать закон и порядок, студенты решили организовать демонстрацию и провозгласить свои требования перед зданием ландтага Нижней Австрии [20, p. 77].

Так начались «три мартовских дня» революции. 13 марта студенты, не имея какоголибо конкретного плана или программы действий, собрались вместе с горожанами и рабочими венских предместий перед зданием парламента на Херренгассе. Спустя какое-то 
время на студентов стали сыпаться насмешки из-за их нерешительности и бездействия. Наконец внимание к себе привлек выпускник Венского университета, молодой доктор медицины Адольф Фишхоф. Он произнес «первую в Австрии свободную речь» [21, р. 129], которая, по мнению М. Баха, «сама по себе была уже революционным действием» [2, c. 63]. В действительности в ней были сформулированы уже знакомые требования из традиционного либерального набора - свобода печати и науки, право на судебную защиту. Любопытно, что эти требования сопровождались призывом к объединению народов Австрии вполне в духе общеимперской патриотической доктрины: «Слабые стороны одной национальности уравняются тогда с добродетелями других, и достоинства всех национальностей еще более развернутся благодаря объединению и, будучи использованы в государственных целях, вознесут Австрию на высоту благоденствия и силы. Вспомним немцев с их высокими стремлениями, с их тяготением к идеалу, вспомним настойчивых, трудолюбивых и выносливых славян, рыцарственных энтузиастов мадьяр, искусных и сообразительных итальянцев и представим себе, что они сообща и потому с возросшими силами трудятся над общими вопросами государства: могут ли быть какие-либо сомнения в том, что Австрия займет тогда импонирующее положение среди европейских государств?» [2, с. 62].

В ответ на речь Фишхофа толпа ответила возгласами в честь императора и «либеральных» представителей императорского дома, а также «криками негодования против системы и требованием об отставке Меттерниха и его “приспешников”» [2, с. 63]. Затем была зачитана речь венгерского революционера Лайоша Кошута о кризисе финансовой системы монархии и необходимости принятия конституции, в которой при этом подчеркивалась «верная и горячая привязанность династии». Описания дальнейших событий современниками представляют картину неорганизованной, хаотично перемещавшейся, пугавшейся разных слухов и паниковавшей толпы из горожан и рабочих, в которой немногочисленные студенты задирали подошедшие для усмирения войска, позволяли себе дерзкие выкрики и выходки. Серьезные, далеко идущие требования, наподобие отмены имущественного ценза, и решения крестьянского вопроса на тот момент прозвучали из уст только одного студента - Ганса Кудлиха (1823-1917), которого никто, по его словам, не слушал [2, с. 74-75].

В целом для событий этих мартовских и последующих дней революции было характерно хождение огромного количества самых разнообразных слухов и выдумок, которые влияли на настроения горожан и студентов и провоцировали их на определенные действия. Воспоминания очевидцев об этих днях содержат фактические ошибки, часто противоречат друг другу и представляют собой скорее отражение частных взглядов и настроений, нежели сколько-нибудь объективное описание происходивших событий. Так, например, они не позволяют установить, почему был открыт огонь по демонстрантам: то ли по приказу командования, то ли самовольно солдатами в случившейся давке. Одними из первых жертв стали задавленная в толпе женщина и застреленный 18-летний студент-математик.

В последующие дни в Вене были распространены листовки со стихами в память жертв 13 марта, в том числе сочиненными студентами. Одно из таких стихотворений «На могиле погибших 13 марта 1848 года» было написано студентом третьего курса факультета права Юлиусом Шедой и содержало следующие строки: «Вы отстояли свои права. / У сыновей Австрии теперь есть свобода, / Прочно и тесно прикованная / К дорогому трону Габсбургов (здесь и далее перевод наш. Ю. Б.)» [28]. Его стихотворение, помимо слов горечи по поводу безвременной кончины товарищей и пафоса в отношении добытой «свободы», вновь свидетельствует о лояльности правящей династии.

Инициированное студентами выступление у ландтага Нижней Австрии активизировало неприятные и опасные для респектабельных жителей Вены слои: целые толпы рабочих из предместий, где располагалось все фабричное производство, двинулись к крепостным стенам города. «Открылся резервуар крупногородской нищеты», и «из кварталов бедноты» на богатую улицу Мариахильферштрассе «хлынул мутный, но неудержимый 
поток голодного, закутанного в рубища пролетариата» [2, с. 95-96]. Не сумев проникнуть внутрь городских стен, толпы бедноты повернули назад, грабя по пути трактиры, пекарни и мясные лавки. В предместьях они учинили грабежи и поджоги, рушили фабрики и машины, в которых видели основной источник своих бедствий и нищеты.

В литературе традиционно утверждается, что студенты искали союза с рабочими в деле свержения старой системы. Однако М. Бах, например, уточняет, что только часть студентов искали такого союза, тогда как «для подавляющего большинства студентов и, особенно, для буржуа содействие пролетариата представлялось очень опасным и неприятным» [2, с. 96]. Известно, что после событий 13 марта студенты стали требовать, чтобы им выдали оружие для самозащиты, в противном случае угрожали сами разнести арсенал. Но оружие им было выдано для защиты не от правительственных войск (несмотря на то впечатление, которое складывается при прочтении большинства исследований), а от того самого пролетариата: студенческие патрули были направлены в рабочие предместья с целью утихомирить взбунтовавшихся путем переговоров, уговоров и лести. Студентам и впрямь удавалось успокоить восстававших, но ропот по возвращении в университет свидетельствует о том, что студенты боялись: они не только осознавали опасность своего патрулирования, но и остерегались ловушки со стороны властей - страшились, что их не впустят назад в город и расстреляют вместе с рабочими [2, с. 96-110]. В студенческой среде начались разногласия. Часть студентов, упирая на то, что они не солдаты, стала отказываться покидать стены города в составе патрулей.

Вооружившиеся студенты создали так называемый Академический легион из приблизительно шести тысяч студентов Венского университета - по словам Антона Фюстера, ставшего капелланом легиона, «самой прекрасной молодежи, которая когда-либо ступала по этой земле» [26, p. 376]. Штаб-квартира легиона разместилась в здании Новой Аулы, которое стало одним из важнейших центров венской революции [21, p. 129]. Выпускник университета Людвиг Август Франкль сочинил в честь этих событий стихотворение, ко- торое было напечатано тиражом в полмиллиона копий и стало своеобразным гимном венских студентов. Оно начиналось пафосными строками: «Кто это смело шагает? / Оружие поблескивает, знамя развевается, / Под громкий барабанный бой идет / Университет» [16]. Сразу стоит отметить, что в ряды легиона входили не только собственно студенты, но и более взрослые, опытные люди - профессоpa, выпускники, докторанты. Командующим легиона был назначен граф Фердинанд фон Коллоредо-Маннсфельд (1777-1848) - крупный фабрикант и политик, всегда выступавший на стороне законной власти.

В «мартовские дни» правительство сделало существенные уступки восставшим. К. фон Меттерних был отправлен в отставку, студентам официально было разрешено вооружение, была отменена цензура и учреждена Национальная гвардия. Когда император Фердинанд I в официальном манифесте пообещал даровать конституцию, студенты устроили праздник в своем вкусе: пышное триумфальное шествие по городу, во время которого их приветствовали «особенными восторгами и похвалами» [2, с. 118]. Во время шествия студенты несли окруженный венком из цветов портрет императора, а венцы встречали его «в таких же формах, как благочестивые христиане приветствуют святые дары» [2, c. 118]. Император же выразил «свою высочайшую признательность гражданам столицы, университету и Политехническому институту “за чувства верности, проявленные ими как в прежние времена, так и при событиях последних дней”» [2, с. 119].

23 марта правительство впервые решилось на создание Министерства народного просвещения взамен имперской комиссии по образованию. Главой нового министерства был назначен профессор права барон Франц фон Зоммаруга (1780-1860), инициировавший обсуждение реформы университетского образования «на основе свободы преподавания и обучения» по образцу «передовых университетов Германии» [22, S. 69]. Для обсуждения проекта 29 марта был сформирован студенческий комитет, проводивший свои собрания в анатомическом зале Новой Аулы.

В результате контакта, который студентам удалось установить с низшими слоями 
населения во время их полупринудительного патрулирования в «мартовские дни», в Аулу стали стекаться бедняки со своими горестями и жалобами, возлагая большие надежды в их решении на студенческий комитет, взявший на себя в конечном итоге исполнение правоохранительных функций в Вене. Студенческие патрули стали дежурить на улицах, охраняя общественный порядок в городе. Помимо этого, студенты оказывали разного рода помощь беднякам: студенты-медики предложили программу медицинского обслуживания, студенты-юристы помогали в трудовом арбитраже, другие студенты оказывали социальную поддержку или занимались сбором денег. Бедняки отвечали трогательной преданностью и позднее выступали даже в роли телохранителей студентов. «Если погибнет один из нас, - говорили они, это не страшно, но если не станет кого-то из этих прекрасных молодых благородных студентов, которым мы обязаны своей свободой, это будет большая трагедия» [26, р. 377].

О том, насколько венцы ценили революционную деятельность студентов, свидетельствует факт переименования в то время улиц, примыкавших к Новой Ауле: Зонненфельсгассе превратилась в Мартовский переулок (Märzgasse), а Пекарский переулок (Bäckergasse) - в Студенческий переулок (Studentengasse) [21, p. 130]. Венское студенчество действительно обрело огромное влияние в политической и общественной жизни столицы. Например, перед обнародованием закона о прессе, отменявшего цензуру, глава нового кабинета министров Франц фон Пиллерсдорф (1786-1862) попросил студентов высказать о нем свое мнение [29, p. 146]. Популярность Академического комитета настолько возросла, что появились инциденты, в которых мошенники, не имеющие к легиону отношения, пользовались именем университета и под видом легионеров вели собственную агитационную деятельность и осуществляли сбор средств. Студенческий комитет был вынужден выпустить специальное «Разъяснение» для жителей Вены о том, что не «каждый, кто носит штюрмер (штюрмер, или «австрийский колпак», - головной убор студентов в XIX в. по образцу красного островерхого колпака якобинцев. - Ю. Б. ), является студентом» и венцам впредь необходимо требовать у тех, кто представляется легионерами, специ- альное удостоверение с печатью комитета, а в случае выявления злоупотреблений и обмана обращаться к студенческой охране в университет, Политехнический институт или Академию художеств [14].

На студенческие собрания в Аулу приходили самые разные люди, имеющие отдаленное отношение к университету, в том числе иностранцы, представители радикальных идей и политические авантюристы, так что к маю большинство присутствовавших на этих собраниях составляли отнюдь не студенты. Сами легионеры впоследствии признавали, что многие «противозаконные эксцессы, которые приписывались общественным мнением Академическому легиону, в действительности всегда совершались лишь отдельными членами легиона, притом зачастую совершенно не но праву втершимися в эту почтенную корпорацию» [2, с. 309]. Например, было бы неверно считать зародившимися в студенческой среде идеи Антона Шютте - авантюриста и подстрекателя из Вестфалии, обладавшего прекрасным ораторским даром и неоднократно выступавшего с речами в Ауле. Большинство студентов увещевали товарищей спокойно ждать обещанной императором конституции, однако октроированная хартия от 25 апреля принесла всеобщее разочарование: вместо всенародного представительства был установлен высокий имущественный ценз, дававший право голоса только ограниченному числу налогоплательщиков.

В мае 1848 г. возник очередной конфликт между правительством и венскими революционерами, в числе которых активно выступали студенты Венского университета. Совместно с рабочими и Национальной гвардией они еще раз подтвердили свои первоначальные требования о введении либеральной конституции. В ходе городского шествия 15 мая, получившего название «Штурмовая петиция», они потребовали отмены апрельской хартии и созыва Учредительного собрания для разработки новой конституции. Другие актуальные политические вопросы, волновавшие широкую общественность того времени, также не остались без внимания студентов: помимо своего красного студенческого знамени они несли плакат с надписью «Теснейшее соединение с Германией» [2, с. 277]. Эта идея входила в програм- 
му немецкого либерализма и после мартовской революции стала такой же ее неотъемлемой частью, как и требование конституции. Однако, как отмечает М. Бах, представление о том, в какую форму должно вылиться германское единство, в головах австрийских немцев было весьма туманным и имело для них второстепенное значение [2, с. 356].

«Штурмовая петиция» была расценена венцами как радикальный революционный акт. К этому моменту жители Вены, особенно респектабельные и консервативно настроенные, уже устали от революционной обстановки, постоянных и необоснованных набатов, вызовов Национальной гвардии, страхов перед грабительскими нападениями голодных пролетариев. Устали венцы и от студентов: они стали явственно озвучивать свои предложения о том, что весь университет пора закрыть, а студентов отправить по домам. 18 мая императорская семья покинула столицу и перебралась в Инсбрук, вызвав растерянность и разногласия в студенческой среде. Распространился слух, что 15 мая грубые студенты позволили насильственные действия в отношении несчастного больного императора. В провинции вспыхнуло негодование против «терроризма венских студентов». В Линце барон фон Гогенбрук выступил как очевидец событий 15 мая, рассказывая «с такими преувеличениями, прикрасами и с таким явным отвращением к венцам, и в особенности к студентам», что присутствовавшие потребовали закрытия венской Аулы, дабы «положить конец хозяйничанью студентов». В Зальцбурге утром 19 мая распространился слух, будто венские повстанцы провозгласили республиканское правление и изгнали императора после кровопролитных столкновений [2, с. 291-300].

В этой ситуации венские власти предприняли попытку распустить Академический легион, о чем был опубликован декрет от 25 мая. Однако студенты воспротивились, апеллируя к тому, что легион был санкционирован самим императором и не может быть распущен в его отсутствие. После того как распространились слухи, что к университету брошены правительственные войска, внутрь городских стен прорвались толпы рабочих, принявшиеся сооружать для студентов баррикады в непосред- ственной близи от университета, причем не только из булыжников, но и из университетской мебели и библиотечных книг [21, p. 130]. По воспоминаниям очевидцев, в случае действительной битвы баррикад было слишком много, они затруднили бы действия самих революционеров: «Они более импонировали и производили художественное впечатление, чем годились бы для настоящей борьбы; большинство было слишком высоко и построено из слишком твердого материала... Самой грандиозной баррикадой была построенная на площади Стефана... На вершине развевалось огромное кроваво-красное знамя, окруженное флагами цветов всех австрийских земель: она была сборным пунктом представителей всех национальностей империи, которые, придя в своих пестрых костюмах, служили живописным украшением для баррикады. Здесь с нескончаемыми ликованиями праздновали братство народов и по этому случаю выпили все вино из архиепископского подвала, объявленное национальной собственностью; по крайней мере, уже 27 мая на воротах архиепископского дворца красовались написанные мелом слова: “Здесь не осталось ни капли вина!”» [2, с. 319].

«День баррикад» 26 мая в литературе традиционно представлен как победа радикального Академического легиона над консервативными и умеренно-либеральными силами. Однако в приведенном отрывке из воспоминаний очевидца строительство баррикад выглядит скорее студенческой шалостью, чем серьезной угрозой властям. К тому же студенты украшали свои баррикады портретами императора, и «была даже одна "императорская баррикада", на фронте которой красовался портрет императора» [2, с. 320]. Власти уступили и отменили декрет о роспуске легиона. Однако занятия в университете были приостановлены. Многие студенты, не являвшиеся уроженцами Вены, были высланы из столицы, в результате чего численность Академического легиона резко упала. Кроме того, консервативно настроенные студенты тоже со временем покинули легион. 19 августа министр внутренних дел обратился к комитету студентов с вопросом о том, какое отношение имеют состоявшиеся в последние дни в Ауле собрания радикального характера к соб- 
ственно студенчеству Вены. Студенческий комитет заявил, что эти собрания были организованы без его согласия и только незначительную часть присутствовавших составляли студенты. После этого Аула была закрыта для народных собраний [2, с. 465-466].

К моменту жестоких октябрьских событий 1848 г. количество студентов, остававшихся в революционном лагере и принявших участие в уличных стычках и боях на баррикадах, было незначительным. После взятия Вены имперской армией под командованием князя Альфреда Виндишгреца (1787-1862) 31 октября остатки Академического легиона были распущены. Некоторые из его членов бежали в Венгрию и вступили в ряды революционной армии, другие попали в тюремное заключение и были принудительно рекрутированы в армию.

После подавления октябрьской революции здание Новой Аулы, единственное специально спроектированное под нужды Венского университета и подаренное ему в 1756 г. императрицей Марией-Терезией, заняли войска и устроили там бараки. По политическим соображениям было невозможно позволить потенциально мятежным студентам вернуться в это «преступное» место. Таким образом, когда Венский университет возобновил занятия в марте 1849 г., у него не было ни определенного местонахождения, ни центрального здания. Институты, составлявшие университет, были временно размещены в разных помещениях, разбросанных по городу, поскольку правительство стремилось не допустить сосредоточения студентов в одном месте [27, p. 147].

Из «завоеваний» венского студенчества 1848 г. при неоабсолютизме сохранилась только свобода преподавания и обучения. В ходе крупных реформ образования при министерстве графа Лео фон Тун-Гогенштейна (1811$1888)$ Венский университет был реорганизован по образцу германских университетов. Наконец, в 1867 г. в конституцию государства была включена до сих пор действующей статья 17, гласившая, что «наука и ее преподавание свободны» [30].

Революционное студенчество на имперских окраинах: Инсбрукский универсиmem. События мартовской революции в Вене поначалу вызвали положительные и даже вос- торженные отклики в провинции. Почти из всех коронных земель студенты отправляли благодарственные обращения к студентам Вены и императору. Студенты Венского университета охотно делились опытом с товарищами из других университетских городов. В частности, они предложили грацским студентам составить петицию относительно свободы печати, гласности судебного разбирательства, свободы обучения и преподавания, а уже 16 марта студенты Грацского университета организовали собственный академический легион и добились разрешения вооружиться. Товарищам из Пражского университета венские студенты также прислали приглашение примкнуть к делу свободы; 16 марта пражские студенты выработали петицию с требованиями, касающимися организации обучения и студенческой жизни. Получив на нее благоприятный ответ от венских властей, студенты устроили большое торжество в честь 500-летия со дня выдачи грамоты на открытие Пражского университета Карлом IV [2, с. 240].

Когда в провинциальный маленький городок Инсбрук с населением около 10000 жителей (административный и культурный центра земли Тироль) дошли новости об отмене цензуры и провозглашении конституции, последовавших за революционными событиями в Вене, студенты и либерально настроенные профессора местного университета поначалу возликовали. На этот момент в университете преподавали примерно 12 профессоров и обучались примерно 300-320 студентов, преимущественно уроженцев Тироля [9, p. 251-252]. Царившие в марте настроения прекрасно иллюстрируют письма студентов родителям, в которых они описывают эйфорию по поводу произошедших 15 марта перемен и выражают свое восхищение учащимися Венского университета, охватившее их при мысли о том, «что есть еще такие студенты в Австрии» [9, р. 252-253]. 19 марта студенты Инсбрука направили коллективное письмо собратьям из Венского университета с выражением своей поддержки и преклонения перед их решительными действиями в борьбе за свободу и справедливость [17]. Сохранились сообщения о праздничных демонстрациях инсбрукских студентов, проходивших в местном театре 18 и 19 марта, а также об официаль- 
ном факельном шествии в честь нового политического порядка.

Поскольку венские товарищи уже добились большей части политических целей студенчества, инсбрукские студенты, поддерживаемые профессорами, потребовали, чтобы им тоже, как и в Вене, выдали оружие и позволили вступать в ряды новой Национальной гвардии для защиты установившегося политического порядка от реакционеров. Уже 18 марта они сформировали четыре студенческие роты и выбрали своих офицеров. На следующий день они получили ружья в местном арсенале и начали патрулировать улицы Инсбрука вместе с отрядами Национальной гвардии. Также инсбрукские студенты и профессора жаждали политического представительства университетской корпорации в местном ландтаге. Это требование было выполнено уже к апрелю 1848 г.: представителю от университета было позволено участвовать в обсуждении проекта новой конституции.

Несмотря на умеренность требований тирольских студентов, местное население проявило недоверчивость по отношению к ним и их революционному энтузиазму. Фермеров, например, больше интересовали экономические уступки, а такие вещи, как свобода печати, о которой твердили студенты, не представляли для них ценности. Одни жители Инсбрука поддерживали студентов, другие относились к ним скептически, третьи считали студентов потенциальными смутьянами и требовали, «чтобы они немедленно возвратились в свои лекционные аудитории» и «чтобы впредь профессора следили за ними более пристально» [9, p. 254].

Местные власти во главе с губернатором графом Клеменсом фон Брандисом (1798$1863)$, несмотря на то, что последний считался реакционером прометтерниховских взглядов, публично признали новый порядок и присоединились к официальным празднованиям. В целом поведение студентов не вызывало особенного беспокойства инсбрукских властей. К тому же надвигалась более серьезная проблема: до тирольцев стали доходить слухи и новости о восстаниях в соседних итальянских землях, а к концу марта 1848 г. тирольские гражданские и военные власти были уже всерьез озабочены вопросом о том, как за- щитить южные области Тироля от вторжения итальянских националистов. Отряды Ломбардского добровольческого корпуса (Corpi Volontari Lombardi или Corpi Franchi Lombardi), используя тактику партизанской войны, попытались отрезать последнюю линию снабжения армии фельдмаршала Йозефа Радецкого (1766-1858), проходившую через Тироль [23]. При этом они также жаждали «освободить» своих италоязычных братьев и сестер в южных регионах Тироля, угрожая своими действиями территориальной целостности этой наследственной земли Габсбургов. Население италоязычных областей Тироля постепенно охватывал «итальянский дух», чему немало способствовали распространяемые итальянскими ирредентистами листовки, воспевающие идею объединения Италии и свержения ига «абсурдного в наш век деспотизма» [32].

Новости и слухи о происходящих на южных границах событиях существенно изменили настроения инсбрукских студентов. К апрелю 1848 г. их первоначальный энтузиазм по отношению к революции сменился полностью верноподданническим отношением к существующему режиму. Широкое распространение получила немецкая национальная идея: именно тогда большинство немецкоязычных тирольских горожан и студентов впервые открыто осознали себя «немцами», в свете чего утвердилось восприятие всего Тироля как «немецкой» земли $[9$, р. 255]. Воззвание «К Академическому легиону» от 25 апреля 1848 г. начиналось словами: «Бьет барабан, прощайте, братья! / Ведет вперед вас черно-краснозолотой / Древний орел с блестящим опереньем, / Указывает славный путь ваших отцов!» [13, S. 227]. Впрочем, представления тирольцев о едином германском отечестве были не менее туманны, чем у прочих австрийских немцев в тот период. Они не признавали свободу итальянских провинций и «не понимали, как итальянцы могли быть настолько неблагодарными, что хотели отпасть от славной Австрии» [2, с. 356].

Студенты Инсбрука стали первыми записываться в ряды добровольческих стрелковых рот, когда губернатор граф Бандис призвал население к их формированию. Были сформированы две так называемые академи- 
ческие стрелковые роты, в состав которых вошли около 300 студентов и несколько профессоров [9, р. 257]. В конце апреля, получив определенную военную подготовку, студенты с воодушевлением отправились из Инсбрука защищать «немецкую» границу в Трентино. В южных областях Тироля они прослужили примерно два месяца, вместе с прочими стрелковыми ротами и регулярными войсками патрулируя вверенную территорию и отбивая атаки Ломбардского добровольческого корпуса. Хотя сколько-нибудь крупных сражений не произошло, случались перестрелки, в которых было ранено несколько студентов, а двое даже погибли. Этот факт нисколько не смутил их товарищей, которые продолжили нести службу, мечтая о военной славе и почестях, будучи уверенными, что «выполняют свое предназначение и отстаивают честь Тироля в бою» [13, S. 61].

Два месяца военной службы в академических стрелковых ротах еще сильнее укрепили верноподданнические чувства студентов. Когда в их расположение пришли известия о событиях в Вене 15 мая, они дружно осудили «скандальное поведение» венских студентов, считая для себя невозможным пойти на предательство императора, «который верит нам, тирольцам, а также нашим клятвам в безусловной ему преданности» $[13$, S. 152]. Нужно отметить, что их реакция резко отличалась от студенчества других университетов, которые все еще продолжали восхищаться венцами, направляя свои делегации в Аулу, чтобы выразить благодарность Венскому студенческому легиону. Например, глава депутации из Грацкого университета во время визита в Аулу в те дни заявил, что достижения 15 и 26 мая «вызвали симпатию во всей Штирии», и передал Венским студентам флаг с цветами Штирии со словами: «Этот флаг освящается вашими руками» $[33, \mathrm{~S} .1]$. Однако уже вскоре «австрийские» народы оставили свои массовые восторги по поводу революционных событий в Вене. Так, в июньском обращении богемского ландтага к императору выражалось негодование по поводу событий 15 мая, содержались заверения в вечной преданности богемцев и готовности защищать монархию: «...мы завидуем счастливому жребию храбрых сынов Тироля. Мы все, как один че- ловек, готовы, когда дело идет о защите короля и свободы, соперничать с испытанными тирольцами не только в любви, но и в верности и мужестве» [2, с. 299].

Перемены в политических настроениях инсбрукского студенчества и их лояльность правящему дому не остались не замеченными со стороны военных властей и членов императорской семьи. Фельдмаршал Радецкий в своем обращении к жителям южного Тироля отмечал «дух стойкой приверженности святому делу нашего императора и суверена», царящий повсюду в «древнем и верном Тироле» [15]. Эрцгерцог Иоганн, сыгравший центральную роль в организации обороны южного Тироля, писал о своем искреннем удовольствии видеть в ротах инсбрукских студентов «благородных, сильных, отважных молодцев образцовых убеждений» [13, S. 238]. В официальном докладе об итальянской кампании австрийской армии 1848 г. было отмечено «достойное поведение» инсбрукских студентов в битве 9 июня 1848 г. [11, S. 56].

В конце июня 1848 г. студенты вернулись домой с южных границ Тироля. Им оказали теплый прием в Инсбруке: город был украшен, и люди выстроились вдоль улиц, приветствуя студентов, словно героев во время триумфального въезда [9, p. 260]. Вновь прибывших даже пригласили на прием к императорской семье, которая бежала из мятежной Вены в Инсбрук в мае 1848 года. Участие инсбрукских студентов в революционных событиях завершилось, даже несмотря на то, что в остальной Европе продолжали идти бои, сражения и демонстрации. Осенью 1848 г. Инсбрукский университет возобновил свою работу и студенты вернулись к своей повседневной жизни.

С этого времени большинство инсбрукских студентов отдалились от своих венских товарищей и осудили октябрьские события в столице. Всего шесть месяцев назад они прославляли студентов из Вены и даже призывали их сражаться бок о бок до смерти за свободу и справедливость. Но теперь они отказывались понимать, почему венские студенты присоединились к возобновившемуся восстанию. Студенчество Инсбрука, как и его либерально настроенную профессуру, вполне устраивало сложившееся положение вещей, 
они не были заинтересованы в фундаментальных революционных и демократических переменах и были удовлетворены тем, чего удалось добиться в начале весны 1848 года.

Впрочем, размах и жестокость, которую революция обрела к осени 1848 г., обусловили сознательный отказ большей части «австрийского» студенчества от радикальных политических идей. Студенты провинциального Инсбрука представляют собой, пожалуй, наиболее яркий пример патриотизма, единодушного отказа от революционных идей и поддержки существующего порядка. В других землях революционные настроения сохранялись некоторое время среди небольшой части студенчества: в Граце была даже «своя маленькая октябрьская революция», на помощь венским повстанцам было направлено несколько сотен человек; маленький Линц отправил в Вену отряд из 205 гвардейцев и 32 студентов; из Зальцбурга в Вену отбыли два профессора с сорока студентами [2, с. 539]. Однако о широкой массовой поддержке венских революционеров в октябре 1848 г. говорить не приходится. К концу ноября были распущены академические легионы во всех городах, студенты сдали оружие и знамена, сняли мундиры и черно-красно-золотые значки, а в следующем году вернулись к учебе.

Результаты. В современной литературе до сих пор превалирует представление о том, что в ходе революционных событий 1848 г. «австрийские» студенты «плечом к плечу» с рабочим классом сражались против правящего режима, на баррикадах и в кровопролитных сражениях отстаивали самые радикальные демократические идеи. Стоит отметить, что, помимо идеологических искажений, характерных для националистической и марксистской историографии, на формирование такого представления большое влияние оказали разнообразные слухи, распространявшиеся в университетской и городской среде уже в тот период. Тем не менее образ «австрийского» студента-радикала и верного союзника рабочих не соответствует исторической реальности, если принимать во внимание не отдельных представителей, а всю совокупность столичного и провинциального студенчества.

В разных регионах полиэтничных и мультикультурных австрийских наследственных земель революционные выступления студентов получили разный размах, их политические убеждения эволюционировали по-разному. Если в столичной Вене студенты инициировали начало революции, выступив в марте 1848 г. с требованиями принятия конституции, введения либеральных и академических свобод, то провинциальное студенчество примкнуло к революционному движению позднее и играло в нем гораздо более скромную роль. На протяжении всех революционных месяцев венские студенты находились в центре политической жизни столицы, успешно удерживали контроль над осажденным городом с помощью созданной ими вооруженной организации - Академического легиона, штаб которого разместили в одном из главных университетских зданий. Провинциальное студенчество, подражая столичному, также создавало свои академические легионы и составляло петиции. Однако, поскольку к моменту начала их активных действий большая часть требований «австрийского» студенчества была уже принята императором, их действия и выступления носили весьма умеренный характер.

Если студенты Венского университета понесли пусть и немногочисленные жертвы в уличных столкновениях с правительственными войсками, провинциальные студенты, не встретив сопротивления городских властей, просто публично праздновали принятие решения о введении конституции и ряда уступок в гражданских правах, чем, по сути, и ограничились их революционные выступления. Студенты провинциального Инсбрука первыми отказались от какого-либо проявления революционных настроений и выразили безусловную поддержку существующему режиму с приближением военной опасности на южных границах Тироля, грозившей потерей италоязычных регионов Габсбургской монархии. В других регионах также не последовало массовой радикализации студенческих настроений. В случае Вены то, что называют радикализацией студенческого движения, следует рассматривать с определенными оговорками.

В отличие от студентов в соседней Германии, у «австрийских» студентов с самого начала был стандартный набор либеральных требований, не отличавшийся особенной сложностью или радикализмом. Специфика их 
требований была большей частью связана с расширением академических свобод и реорганизацией процесса обучения. На протяжении всех революционных событий, вплоть до взятия Вены имперскими войсками в октябpe 1848 г., студенты оставались лояльными правящей династии. Первое время официальные власти даже поддерживали деятельность Академического легиона и выражали благодарность студентам за их неравнодушное участие в сложившихся обстоятельствах. Карательные меры были применены уже к единицам оставшихся в легионе на последнем этапе революции, так как большая часть студентов его покинули из собственных убеждений или будучи вынужденными уехать из Вены после закрытия университета.

В целом участие студенчества в революционных событиях 1848 г. привело к политизации студентов, о чем свидетельствует резко возросшее число их политических заявлений и требований, изложенных в сотнях сохранившихся петиций, листовок и памфлетов. В революционные месяцы была установлена связь между студентами разных университетов, которая укрепилась в последующие годы и десятилетия настолько, что студенческие протесты в одном городе часто вызывали протесты в университетах других городов, особенно в конце XIX века. Таким образом, одним из результатов революции 1848 г. стало сплочение «австрийского» студенчества в рамках самостоятельной социальной группы, обладающей определенными поведенческими характеристиками и особой «духовной близостью».

\section{ПРИМЕЧАНИЕ}

${ }^{1}$ Исследование выполнено при финансовой поддержке РФФИ в рамках научного проекта № 19-59-23005 «Монархия Габсбургов: новые направления в изучении экономического, социальнополитического и национального развития композитарного государства Центральной Европы».

The reported study was funded by RFBR according to research project no. 19-59-23005 "The Habsburg Monarchy: New Directions in the Study of the Economic, Socio-Political and National Development of the Composite State of Central Europe".

\section{СПИСОК ЛИТЕРАТУРЫ}

1. Авербух, Р. А. Революция в Австрии (18481849 гг.) / Р. А. Авербух. - М. : Наука, 1970. - 246 с.

2. Бах, М. Австрия в первую половину XIX века / М. Бах. - СПб. : Изд. С. Скирмунта : Тип. Н.П. Собко, 1906. -670 c.

3. Европейские революции 1848 года. «Принцип национальности» в политике и идеологии / отв. ред. С. М. Фалькович. - М. : Индрик, 2001. -456 с.

4. Кан, С. Б. Революция 1848 года в Австрии и Германии / С. Б. Кан. - М. : Учпедгиз, 1948. - 232 с.

5. Освободительные движения народов Австрийской империи : Возникновение и развитие. Конец XVIII в. -1849 г. / под ред. В. И. Фрейдзона. M. : Наука, 1980. -609 c.

6. Политические партии и общественные движения в монархии Габсбургов, 1848-1914 гг. Очерки / отв. ред. О. В. Хаванова. - М. : Индрик, 2018. 418 c. - DOI: $10.31168 / 91674-503-0$.

7. Тарле, Е. В. Роль студенчества в революционном движении в Европе в 1848 году // Сочинения. В 12 т. Т. 1 / Е. В. Тарле. - М. : Изд-во АН РАН, 1957. - C. 586-604.

8. Шарый, А. Австро-Венгрия. Судьба империи / А. Шарый, Я. Шимов. - М. : Колибри, 2017. $445 \mathrm{c}$.

9. Aichner, Ch. "Für den Kaiser ersholl in unserem Lager nichts als Jubel": Students Between Revolutionary and Loyal Sentiments - The Curious Case of Innsbruck in 1848 / Ch. Aichner, M. Egger // Student Revolt, City and Society in Europe: From Middle Ages to the Present / ed. by P. Dhondt, E. Boran. - N. Y. : Routledge, 2017. - P. 251-268.

10. Bakke, W. Roots and Soil of Student Activism // Comparative Education Review/ W. Bakke. - 1966. № 10. - P. 163-174.

11. Der Feldzug der österreichischen Armee in Italien im Jahre 1848. - Wien : Aus der k.-k. Hof- und Staatsdruckerei, 1852. - 136 S.

12. Dhondt, P. Students as Agents of Changes? / P. Dhondt, L. Kolbe // Student Revolt, City and Society in Europe: From Middle Ages to the Present / ed. by P. Dhondt, E. Boran. - N. Y. : Routledge, 2017. - P. 1-8.

13. Egger, M. "Für Gott, Kaiser und Vaterland zu Stehen oder zu Fallen..." Die Aufzeichnungen Joseph Hundeggers aus dem Revolutionsjahr 1848 / M. Egger. Innsbruck : Universitätsverlag, 2012. - 536 S.

14. Erklärung der Studenten Wiens // Flugblätter aus dem Revolutionsjahr 1848 in der Habsburger Monarchie / ÖNB Labs. - Electronic text data. - Mode of access: https://labs.onb.ac.at/de/dataset/1848/ (date of access: 31.01.2020). - Title from screen.

15. Feld-Maresciallo Conte Radetzky agli abitanti del Tirolo Meridionale. Verona, il 6 Aprile 1848 // ÖNB- 
ANNO. - Electronic text data. - Mode of access: http:/ /anno.onb.ac.at/cgi-content/anno-plus?aid=flu\&datum= 0033 \&page $=8 \&$ size $=45$ (date of access: 31.01 .2020$)$. Title from screen.

16. Frankl, L. A. Die Universität. Wien, 1848 / L. A. Frankl // Universität Wien. - Electronic text data. - Mode of access: https:/geschichte.univie.ac.at/ en/topics/what-approaches-bold-strides (date of access: 31.01 .2020 ). - Title from screen.

17. Gruß an die Studenten Wien's von den Studenten Innsbruck's // ÖNB-ANNO. - Electronic text data. - Mode of access: http://anno.onb.ac.at/ cgi-content/anno-plus?aid $=$ flu $\&$ datum $=0033 \&$ page $=2 \&$ size $=45$ (date of access: 31.01 .2020$)$. - Title from screen.

18. Heintl, C. R. von. Mittheilungen aus den Universitäts-Acten (vom 12. März bis 22. Juni 1848) / C. R. von Heintl. - Wien : [s. n.], 1848. - 88 S.

19. Komleva, Yu. Instilling the Idea of "Double" Identity: History Curriculum in the Schools of AustroHungary / Yu. Komleva // Re-thinking European Politics and History : IWM Junior Visiting Fellows' Conference Papers. - 2012. - № 32. - Electronic text data.-Mode of access: http://www.iwm.at/publications /5-junior-visiting-fellows-conferences/vol-xxxii/ instilling-the-idea-of-double-identity/ (date of access: 31.01.2020). - Title from screen.

20. Maisel, T. Freedom of Teaching and Learning and the First Steps Towards a University and Academic Reform in the Revolutionary Year of 1848 / T. Maisel // The Thun-Hohenstein University Reforms 1849-1860: Conception - Implementation - Aftermath / ed. by Ch. Aichner, B. Mazohl. - Wien : Böhlau Verlag, 2017.P. 77-92.

21. Maisel, T. Vormärz, the 1848 Revolution and the Loss of the Old University / T. Maisel // Sites of Knowledge: The University of Vienna and its Buildings. A History 1365-2015 / ed. by J. Rüdiger, D. Schweizer. Wien : Böhlau Verlag, 2015. - P. 121-136.

22. Meister, R. Entwicklung und Reformen des österreichischen Studienwesens. Teil 1 / R. Meister. Wien : Böhlau 1963.-274 S.

23. Moos, C. Intorno ai volontari lombardi del 1848 / C. Moos // Il Risorgimento. - 1984. - Vol. 36, № 2. - P. 113-159.

24. Pinner, F. A. Students - A Marginal Elite in Politics / F. A. Pinner // The Annals of the American Academy of Political and Social Science. - 1971. Vol. 395. - P. 127-138.

25. Rath, J. The Failure of an Ideal: The Viennese Revolution of 1848 / J. Rath // The Southwestern Social Science Quarterly. - 1953. - Vol. 34, № 2. - P. 3-20.

26. Robertson, P. Students on the Barricades: Germany and Austria, 1848 / P. Robertson // Political Science Quarterly. - 1969. - Vol. 84, № 2. - P. 367 379.
27. Rüdiger, J. Siteless Knowledge? The University's Dislocation and the Search for a Site for the New Biuilding / J. Rüdiger // Sites of Knowledge: The University of Vienna and its Buildings. A History 1365-2015 / ed. by J. Rüdiger, D. Schweizer. - Wien : Böhlau Verlag, 2015. - P. 147-154.

28. Scheda, J. Bei idem Grabe der am 13. März 1848 Gefallenen von ihren trauernden Mitbrüdern. Wien, 1848 / J. Scheda //ÖNB-ANNO. - Electronic text data. - Mode of access: URL: http://anno.onb.ac.at/cgi-content/annoplus?aid $=$ flu\&datum $=0003 \&$ page $=5 \&$ size $=50$ (date of access: 31.01.2020). - Title from screen.

29. Schurz, C. The Reminiscences of Carl Schurz. In 3 vols. Vol. 1 / C. Schurz. - N. Y. : The McClure Company, 1907. $-472 \mathrm{p}$.

30. Staatsgrundgesetz über die allgemeinen Rechte der Staatsbürger, 23.12.1867. Artikel 17. // RGBl. Nr. 142/1867 / Rechtsinformationssystem des Bundes. - Electronic text data. - Mode of access: https://www.ris.bka.gv.at/Ergebnis.wxe?Abfrage= Bundesnormen \&Titel=STGG\&VonArtikel=17 (date of access: 31.01.2020). - Title from screen.

31. Student Revolt, City and Society in Europe: From Middle Ages to the Present / ed. by P. Dhondt, E. Boran. - N. Y. : Routledge, 2017. -436 p.

32. Viva l'Italia! - Trento: Tipografia Monauni. 29 Marzo 1848 // ÖNB-ANNO. - Electronic text data. Mode of access: http://anno.onb.ac.at/cgi-content/ anno-plus? aid $=$ flu $\&$ datum $=0033 \&$ page $=6 \&$ size $=45$ (date of access: 31.01 .2020$)$. - Title from screen.

33. Wiener Studenten-Blatt. 1848. 7 Juni (№ 1) // Love, P. Wiener Studenten-Blatt / P. Love. - Wien : Ludwig, 1848. - Electronic text data. - Mode of access: https://books.google.ru/books?id=_8JeAA AAcAAJ\&dq $=$ Wiener + Studenten-Blatt $\& \bar{h} \mathrm{l}=$ ru\& source $=$ gbs navlinks $s$ (date of access: 31.01 .2020$)$. Title from screen.

\section{REFERENCES}

1. Averbukh R.A. Revolyutsiya v Avstrii (1848$1849 \mathrm{gg}$.) [The 1848-1849 Revolution in Austria]. Moscow, Nauka Publ., 1970. 246 p.

2. Bakh M. Avstriya v pervuyu polovinu XIX veka [Austria in the First Half of the $19^{\text {th }}$ Century]. Saint Petersburg, Izdanie S. Skirmunta, Tipografiya N.P. Sobko, 1906. 670 p.

3. Falkovich S.M., ed. Evropeyskie revolyutsii 1848 goda. «Printsip natsionalnosti»v politike $i$ ideologii [European Revolutions of 1848. "Nationality Principle" in Politics and Ideology]. Moscow, Indrik Publ., 2001. 456 p.

4. Kan S.B. Revolyutsiya 1848 goda v Avstrii i Germanii [Revolution of 1848 in Austria and Germany]. Moscow, Uchpedgiz, 1948. 232 p. 
5. Freydzon V.I., ed. Osvoboditelnye dvizheniya narodov Avstriyskoy imperii: Vozniknovenie i razvitie. Konets XVIII v. $-1849 \mathrm{~g}$. [Liberation Movements of Peoples in the Austrian Empire: Emergency and Development. From the Late $18^{\text {th }}$ Century to 1849]. Moscow, Nauka Publ., 1980. 609 p.

6. Khavanova O.V., ed. Politicheskie partii $i$ obshchestvennye dvizheniya $v$ monarkhii Gabsburgov, 1848-1914 gg. Ocherki [Political Parties and Social Movements in the Habsburg Monarchy, 1848-1914. Essays]. Moscow, Indrik Publ., 2018. 418 p. DOI: 10.31168/91674-503-0.

7. Tarle E.V. Rol studenchestva v revolyutsionnom dvizhenii v Evrope v 1848 godu [Role of Students in the Revolutionary Movement in Europe in 1848]. Sochineniya. V 12 t. T. 1 [Works in 12 Vols. Vol. 1]. Moscow, Izd-vo AN RAN, 1957, pp. 586-604.

8. Sharyy A. Avstro-Vengriya. Sudba imperii [Austro-Hungary. Empire's Destiny]. Moscow, Kolibri Publ., 2017. 445 p.

9. Aichner Ch., Egger M. "Für den Kaiser ersholl in unserem Lager nichts als Jubel": Students Between Revolutionary and Loyal Sentiments - The Curious Case of Innsbruck in 1848. Dhondt P., Boran E., eds. Student Revolt, City and Society in Europe: From Middle Ages to the Present. New York, Routledge, 2017,pp. 251-268.

10. Bakke W. Roots and Soil of Student Activism. Comparative Education Review, 1966, no. 10, pp. 163-174.

11. Der Feldzug der österreichischen Armee in Italien im Jahre 1848. Wien, Aus der k.-k. Hof- und Staatsdruckerei, 1852.136 S.

12. Dhondt P., Kolbe L. Students as Agents of Changes? Dhondt P., Boran E., eds. Student Revolt, City and Society in Europe: From Middle Ages to the Present. New York, Routledge, 2017, pp. 1-8.

13. Egger M. "Für Gott, Kaiser und Vaterland zu Stehen oder zu Fallen...” Die Aufzeichnungen Joseph Hundeggers aus dem Revolutionsjahr 1848. Innsbruck, Universitätsverlag, 2012. $536 \mathrm{~S}$.

14. Erklärung der Studenten Wiens. Flugblätter aus dem Revolutionsjahr 1848 in der Habsburger Monarchie. ÖNB Labs. URL: https://labs.onb.ac.at/ de/dataset/1848/ (accessed 31 January 2020).

15. Feld-Maresciallo Conte Radetzky agli abitanti del Tirolo Meridionale. Verona, il 6 Aprile 1848. ÖNB$A N N O$. URL: http://anno.onb.ac.at/cgi-content/annoplus?aid $=$ flu $\&$ datum $=0033 \&$ page $=8 \&$ size $=45$ (accessed 31 January 2020).

16. Frankl L.A. Die Universität. Wien, 1848. Universität Wien. URL: https://geschichte.univie.ac.at/ en/topics/what-approaches-bold-strides (accessed 31 January 2020).

17. Gruß an die Studenten Wien's von den Studenten Innsbruck's. ÖNB-ANNO. URL: http:// anno.onb.ac.at/cgi-content/anno-plus?aid=flu\& datum $=0033 \&$ page $=2 \&$ size $=45$ (accessed 31 January 2020).

18. Heintl C.R. von. Mittheilungen aus den Universitäts-Acten (vom 12. März bis 22. Juni 1848). Wien, [s. n.], 1848. $88 \mathrm{~S}$.

19. Komleva Yu. Instilling the Idea of "Double" Identity: History Curriculum in the Schools of AustroHungary. Re-thinking European Politics and History: IWM Junior Visiting Fellows' Conference Papers, 2012, no. 32. URL: http://www.iwm.at/publications/5junior-visiting-fellows-conferences/vol-xxxii/instillingthe-idea-of-double-identity/ (accessed 31 January 2020).

20. Maisel T. Freedom of Teaching and Learning and the First Steps Towards a University and Academic Reform in the Revolutionary Year of 1848. Aichner Ch., Mazohl B., eds. The Thun-Hohenstein University Reforms 1849-1860: Conception - Implementation Aftermath. Wien, Böhlau Verlag, 2017, pp.77-92.

21. Maisel T. Vormärz, the 1848 Revolution and the Loss of the Old University. Rüdiger J., Schweizer D., eds. Sites of Knowledge: The University of Vienna and Its Buildings. A History 1365-2015. Wien, Böhlau Verlag, 2015, pp. 121-136.

22. Meister R. Entwicklung und Reformen des österreichischen Studienwesens. Teil 1. Wien, Böhlau, 1963.274 S.

23. Moos C. Intorno ai volontari lombardi del 1848. Il Risorgimento, 1984, vol. 36, no. 2, pp. 113-159.

24. Pinner F.A. Students - A Marginal Elite in Politics. The Annals of the American Academy of Political and Social Science, 1971, vol. 395, pp. 127-138.

25. Rath J. The Failure of an Ideal: The Viennese Revolution of 1848. The Southwestern Social Science Quarterly, 1953, vol. 34, no. 2, pp. 3-20.

26. Robertson P. Students on the Barricades: Germany and Austria, 1848. Political Science Quarterly, 1969, vol. 84, no. 2, pp. 367-379.

27. Rüdiger J. Siteless Knowledge? The University's Dislocation and the Search for a Site for the New Biuilding. Rüdiger J., Schweizer D., eds. Sites of Knowledge: The University of Vienna and Its Buildings. A History 1365-2015. Wien, Böhlau Verlag, 2015, pp. 147-154.

28. Scheda J. Bei idem Grabe der am 13. März 1848 Gefallenen von ihren trauernden Mitbrüdern. Wien, 1848. ÖNB-ANNO. URL: http://anno.onb.ac.at/cgicontent/anno-plus?aid =flu $\&$ datum $=0003 \&$ page $=5 \&$ size $=50($ accessed 31 January 2020$)$.

29. Schurz C. The Reminiscences of Carl Schurz. In 3 Vols. Vol. 1. New York, The McClure Company, 1907. $472 \mathrm{p}$.

30. Staatsgrundgesetz über die allgemeinen Rechte der Staatsbürger, 23.12.1867. Artikel 17. RGBl, Nr. 142/1867. Rechtsinformationssystem des Bundes. URL: https://www.ris.bka.gv.at/Ergebnis.wxe?Abfrage 
Ю.Е. Бут. Между бунтом и преданностью: студенчество Австрийской империи в революционных событиях

$=$ Bundesnormen \&Titel=STGG\&VonArtikel $=17$ (accessed 31 January 2020).

31. Dhondt P., Boran E., eds. Student Revolt, City and Society in Europe: From Middle Ages to the Present. New York, Routledge, 2017. 436 p.

32. Viva l'Italia! - Trento: Tipografia Monauni. 29 Marzo 1848. ÖNB-ANNO. URL: http://anno.onb.ac. at/cgi-content/anno-plus?aid=flu\&datum $=0033$ \&page $=6 \&$ size $=45$ (accessed 31 January 2020).

33. Wiener Studenten-Blatt. 1848. 7 Juni (№ 1). Love P. Wiener Studenten-Blatt. Wien, Ludwig, 1848. URL: https://books.google.ru/books?id= 8 JeAAAAcAAJ\&dq=Wiener+Studenten-Blatt\&hl= ru\&source=gbs_navlinks_s (accessed 31 January 2020).

\section{Information About the Author}

Julija E. But, Candidate of Sciences (History), Associate Professor, Department of Modern and Contemporary History, Ural Federal University named after the first President of Russia B.N. Yeltsin, Turgeneva St., 4,620083 Yekaterinburg, Russian Federation, komleva79@mail.ru, j.e.komleva@at.urfu.ru, https://orcid.org/0000-0003-4105-2387

\section{Информация об авторе}

Юлия Евгеньевна Бут, кандидат исторических наук, доцент кафедры новой и новейшей истории, Уральский федеральный университет им. первого Президента России Б.Н. Ельцина, ул. Тургенева, 4, 620083 г. Екатеринбург, Российская Федерация, komleva79@mail.ru, j.e.komleva@at.urfu.ru, https://orcid.org/0000-0003-4105-2387 